\title{
Az eleséstől való félelem otthon élő idősek körében
}

\author{
Kovács Éva dr. ${ }^{1}$ - Erdős Réka Laura ${ }^{1}$ - Petridisz Anna Niké ${ }^{1}$ \\ Rozs Franciska ${ }^{1}$. Simon András ${ }^{2}$ \\ ${ }^{1}$ Semmelweis Egyetem, Egészségtudományi Kar, Alapozó Egészségtudományi Intézet, \\ Morfológiai és Fiziológiai Tanszék, Budapest \\ ${ }^{2}$ Semmelweis Egyetem, Egészségtudományi Kar, Alkalmazott Egészségtudományi Intézet, \\ Fizioterápia Tanszék, Budapest
}

\begin{abstract}
Bevezetés: Az eleséstől való félelem miatt az idősek visszafogják mindennapi tevékenységüket, ami az izomzat meggyengülésén és az egyensúly hanyatlásán keresztül ahhoz vezethet, hogy az idős emberek intézeti elhelyezésre szorulnak. Emiatt az eleséstől való félelem komoly probléma az idősek körében. Prevalenciáját, összefüggő tényezőit, valamint a megelőzés és a kezelés lehetőségeit egyre szélesebb körben vizsgálják a geriátriában.

Célkitüzés: Leírni az eleséstől való félelem gyakoriságát és összefüggését demográfiai (életkor, nem), valamint egészségbeli (az idős életszakaszra jellemző krónikus betegségek, funkcionális mobilitás, korábbi elesés, gyógyszerszedés) tényezőkkel otthon élő idősek körében.

Módszer: 200 személy vett részt a kutatásban. Az eleséstől való félelem fennállását a rövid Falls Efficacy Scale - International (FES-I) skálának a geriátriai szakirodalomban publikált határértéke alapján diagnosztizáltuk. Logisztikus regresszióval vizsgáltuk az összefüggéseket.

Eredmények: Összesen 61 résztvevőnél volt kimutatható az eleséstől való kóros mértékủ félelem. Mintánkban az eleséstôl való félelem az életkorral, a krónikus betegségek számával és a hanyatló funkcionális mobilitással mutatott összefüggést.

Következtetés: Az egyszerűen és gyorsan kitölthető, magyar nyelven is validált rövid FES-I kérdőívvel elsősorban a magasabb életkorú, több krónikus betegségben szenvedő időseket érdemes szürni, hogy azonosítsuk azokat, akik további részletes kivizsgálásra, majd ennek eredménye alapján célzott beavatkozásra szorulnak.
\end{abstract}

Orv Hetil. 2019; 160(5): 191-197.

Kulcsszavak: eleséstől való félelem, prevalencia, rizikótényező, FES-I magyar változat, idős emberek

\section{Fear of falling among community-living older adults}

Introduction: Due to fear of falling, older people may restrict their activities, causing muscle weakness and impaired balance and, consequently, admission to an institute. Accordingly, fear of falling is a common and serious health problem among older individuals. The prevalence of the fear of falling and its associated factors as well as possible preventive and therapeutic methods have been widely investigated in geriatrics.

Aim: The aim of our study was to describe the prevalence of the fear of falling and its associations with demographic (age, gender) and health factors (age-related chronic diseases, functional mobility, falling in the previous year, medications) among community-living older adults.

Method: Two-hundred individuals participated in the study. The fear of falling was diagnosed based on the cut-off value of the short Falls Efficacy Scale - International (FES-I). Logistic regression analysis was used to assess associations. In total, 61 participants were diagnosed with fear of falling.

Results: In our sample, the fear of falling was associated with age, the number of diseases and functional mobility. Conclusion: The short FES-I is simple, easy to fill-out and has a validated Hungarian version as well. By its use, people of higher age affected by multiple chronic illnesses are primarily worth of screening in order to identify those who are in need for further more detailed examinations and, if needed, more targeted interventions.

Keywords: fear of falling, prevalence, risk factors, FES-I Hungarian version, older people

Kovács É, Erdős RL, Petridisz AN, Rozs F, Simon A. [Fear of falling among community-living older adults]. Orv Hetil. 2019; 160(5): 191-197.

(Beérkezett: 2018. augusztus 2.; elfogadva: 2018. augusztus 27.) 


\section{Rövidítések}

$\mathrm{BMI}=($ body mass index $)$ testtömegindex $; \mathrm{CI}=($ confidence interval) konfidenciaintervallum; FES-I $=($ Falls Efficacy Scale - International) az eleséstôl való félelmet mérő nemzetközi kérdőív; OR $=($ odds ratio $)$ esélyhányados; TUG test $=($ timed up and go test) időzített felállási és járási teszt; UN DESA = (United Nations Department of Economic and Social Affairs) az Egyesült Nemzetek Szervezetének Gazdasági és Szociális Ügyek Főosztálya

Az idős korosztály nagy és egyre növekvő csoportját teszi ki a fejlett társadalmak teljes populációjának. A UN DESA szerint a 65 év felettiek száma 1990 és 2000 között 16\%-kal nőtt. Az elkövetkező 20 évben ez a létszámnövekedés felgyorsul, 2050-re a lakosság több mint egynegyede (26\%) 65 évnél idősebb lesz [1].

Az idősek körében komoly problémát jelent az eleséstől való félelem. Ezt a jelenséget a szakirodalomban legelőször Bhala említette 'ptofóbia' (ptophobia) néven, mellyel az álló helyzetben vagy járáskor fellépő fóbiás reakcióval járó intenzív félelemre utalt [2]. A későbbi elnevezés, a Murphy által bevezetett 'elesés utáni szindróma' (post-fall syndrome) azt tükrözi, hogy akkoriban a jelenséget az elesés közvetlen következményének tartották [3]. További kutatások azonban kimutatták, hogy olyan időseknél is tapasztalható, akik korábban egyszer sem estek el $[4,5]$. Egy vizsgálatban a 77 év feletti idősek 40\%-a azt mondta, hogy fél attól, hogy a napi életviteléhez kötődő tevékenységei közben elesik, és ezen idősek 23\%-a annak ellenére félt az eleséstól, hogy korábban nem esett el [4]. Ezért újabban 'eleséstől való félelem'nek (fear of falling) nevezik a jelenséget [6].

Az eleséstől való félelem az idősek jelentős hányadát érinti. A felmérések szerint az otthon élő, önálló életvitelt folytató idősek 24-54\%-ánál tapasztalható [7-10]. Tinetti és Powell szerint ez olyan állapot, amikor az idős ember állandóan az elesésre vagy annak veszélyére gondol, és emiatt végül is korlátozza mindennapi tevékenységeit [11]. Mindez az izmok gyengüléséhez, az egyensúly-szabályozó rendszer funkcionális hanyatlásához vezethet, ilyen módon növeli egy jövőbeli elesés rizikóját $[4,12]$. Ez a folyamat az idős ember önálló életvitelét veszélyeztetve növeli az intézeti ellátásba kerülés lehetőségét. Cumming és mtsai prospektív vizsgálata szerint az eleséstől való félelem az ötszörösére növeli a tartós intézményi ellátásba kerülés kockázatát (OR: 4,94, 95\% CI: $1,14-21,58)[4]$.

Az eleséstől való félelem csökkentésére számos mozgásprogramot kifejlesztettek, melyek akkor képesek hatásosan megakadályozni vagy megállítani az önállóság elvesztéséhez vezető folyamatot, ha időben felismerjük a veszélyeztetett egyéneket [13]. Ehhez fontos egyrészt tudnunk azt, hogy az idős korosztály mekkora rétegét érinti az eleséstôl való félelem, másrészt mélyebben megismernünk azt, hogy ez a félelem milyen tényezőkkel áll kapcsolatban.
Az eddigi kutatások szerint az eleséstől való félelemnek az életkorral és a nemmel való összefüggése nem konzisztens. Egyes kutatások eredményei szerint szignifikánsan gyakoribb az eleséstől való félelem a nők és a magasabb életkorúak között $[8,10,14]$. Ezzel szemben más kutatások nem igazolták az eleséstôl való félelemnek az összefüggését az életkorral, valamint a nemmel [5, 15]. Az eleséstól való félelem és az elesés kapcsolatát a kutatások többsége bizonyította. A retrospektív kutatások eredményei arra mutattak rá, hogy a korábbi elesés után gyakrabban alakul ki félelem egy újabb eleséstől $[8$, $10,14]$. A prospektív kutatások szerint fordított kapcsolat is fennállhat közöttük: azoknál az időseknél, akik félnek az eleséstől, nagyobb egy elkövetkező elesés kockázata [4, 16, 17]. Ugyanakkor Gillespie nem tudott összefüggést kimutatni az eleséstôl való félelem és az elesés között: több mint 40\%-os prevalenciát becsült azon idősek között is, akik elestek a megkérdezést megelőző 12 hónapon belül, és azok között is, akik nem [18]. A kutatások többsége szerint az eleséstől való félelem szignifikáns kapcsolatot mutat a bizonytalanabb egyensúllyal és a hanyatló járásképességgel $[8,9,15,18,19]$. Mind az egyensúly, mind a járásképesség rosszabb azoknál az időseknél, akik azt vallották, hogy félnek az eleséstől. A krónikus betegségek hatását tekintve a kutatások azt mutatták, hogy azoknál az időseknél, akik az idős életszakaszra jellemző krónikus betegségek (diabetes mellitus, osteoporosis, cardialis, respiratorikus, az alsó végtagot érintô mozgásszervi, a mozgásképességet is befolyásoló neurológiai betegség, mint például Parkinsonkór, stroke) valamelyikében szenvedtek, gyakrabban vallották, hogy napi életvitelük során félnek az eleséstôl [4, $17,20]$.

Jelenleg nem ismerjük, hogy a magyar, otthon élő idősek körében milyen gyakori és milyen mértékű az eleséstől való félelem, valamint hogy van-e kapcsolata azokkal a tényezókkel, amelyek összefüggését nemzetközi kutatásokban már vizsgálták és részben igazolták. Keresztmetszeti kutatásunk célja az volt, hogy magyar, otthon élő idősek körében felmérjük az eleséstől való félelem mértékét és gyakoriságát, valamint hogy ezeket összevessük a nemzetközi adatokkal. Továbbá annak vizsgálatát is célul tűztük ki, hogy az eleséstől való félelemnek van-e kapcsolata demográfiai (életkor, nem), valamint egészségbeli (az idős életszakaszra jellemző krónikus betegségek, funkcionális mobilitás, korábbi elesés, gyógyszerszedés) tényezőkkel.

\section{Módszer}

\section{Résztvevök}

A kutatás résztvevőit idősklubokban, egyházaknál, valamint kerületi újságban megjelentetett hirdetés alapján toboroztuk. A kutatásban azok a 60 éves vagy annál idősebb személyek vehettek részt, akik járási segédeszközzel vagy a nélkül járóképesek voltak. Kizártuk a részvételből 
azokat, akik intézményi keretek között, például idősotthonokban éltek, illetve akiknél olyan érzékszervi vagy kognitív eredetü kommunikációs zavar állt fenn, mely őket az adatlap és a kérdőív kitöltésére képtelenné tette volna.

A fenti kritériumok szerint kiválasztott résztvevők előzetes tájékoztatás után írásban járultak hozzá a részvételhez. Felhívtuk a figyelmüket arra a jogukra, hogy a kutatás bármelyik fázisában visszaléphetnek a részvételtől.

\section{Mérések}

Kutatásunkban önkitöltős adatlappal, valamint fizikális mérésekkel gyưjtöttünk adatokat a toborzás helyszínén (klubterem, kultúrház, közösségi ház, egyházi közösségi helyszínek, parókia, plébánia).

$\mathrm{Az}$ adatlapon feltett kérdésekkel nyertünk adatokat a demográfiai jellemzőkről (életkor, nem, családi állapot), a gyógyszerszedésről (rendszeresen szedett gyógyszerek), valamint az egészségi állapotról (diabetes mellitus, osteoporosis, cardialis, respiratorikus, az alsó végtagot érintő mozgásszervi, a mozgásképességet is befolyásoló neurológiai betegség [Parkinson-kór, stroke]).

$\mathrm{Az}$ adatlapon szerepelt a rövid FES-I kérdőív is, melynek már a magyar nyelvű verziója is validálva van [21]. A kérdőív arra kérdez rá, hogy mennyire foglalkoztatja az idős embert egy esetleges elesés az otthoni és a közösségi élet gyakori tevékenységei közben. A kérdőív öt, lakótéren belüli (öltözködés, tisztálkodás, székre leülés és felállás, lépcsőn járás, tárgyak talajról való felvétele) és két nehezebb kültéri tevékenységet (lejtős talajon járás, társasági eseményekre eljutás) vizsgál. A választ az idős ember négyfokú skálán jelölheti meg: az elesés egyáltalán nem foglalkoztat $=1$; egy kissé foglalkoztat $=2$; meglehetősen foglalkoztat $=3$; nagyon foglalkoztat $=4$. A válaszok pontszámát összeadva egyetlen indexet képezünk, így az elérhető összpontszám 7 és 28 között lehet: minél alacsonyabb az összpontszám, annál kevésbé nyugtalankodik az elesés miatt az idős személy a napi tevékenységek végzése során [22]. A 10-es határérték és az a feletti összpontszám kóros mértékú félelmet jelez [23]. A magyar nyelvű verziónak - az egyéb nyelvű verziókhoz hasonlóan - kiváló az ismételt méréses megbízhatósága (ICC $=0,831$ ) és a belső konzisztenciája (Cronbach-alfa koefficiens $=0,93)$ [21].

A funkcionális mobilitás vizsgálatára a 'timed up and go' (TUG-) tesztet használtuk, melyet az idősek mérésére széleskörüen alkalmaznak [24]. A teszt során másodpercben mértük azt az időtartamot, amely alatt a vizsgált személy felállt egy $46 \mathrm{~cm}$ magas $(65 \mathrm{~cm}$ magasságban karfás) székről, biztonságos tempóban, valamint a megszokott lábbeliben elsétált egy 3 m távolságban lévő jelzésig, azt megkerülve visszasétált, és ismét leült a székre. Szükség esetén a résztvevők használhatták a korábban is megszokott járási segédeszközüket, kezükre támaszkodhattak a felálláskor, de más fizikális segítségben nem részesülhettek. Két egymást követő kivitelezés átlagát szá- mítottuk, melyek között 30 másodperces pihenőt tartottunk. A méréshez stopperórát használtunk, melyet a „rajt” jelzés elhangzása után indítottunk el, és akkor állítottuk meg, amikor a személy háta nekitámaszkodott a háttámlának. A feladathoz szükséges hosszabb tesztidő rosszabb teljesítményt jelez. A tesztnek kiváló az ismételt méréses (ICC $=0,99$ ) és a megfigyelők közti megbízhatósága $(\mathrm{ICC}=0,99)[25]$.

\section{Statisztikai elemzés}

A minta leíró elemzéséhez átlagot, szórást, abszolút és relatív gyakoriságot számítottunk. Az adatok normalitásáról az eloszlás ferdesége, valamint a Shapiro-Wilk-teszt eredménye alapján döntöttünk. Az alábbi változókról nyert folyamatos adatokat a következőképpen dichotomizáltuk:

- eleséstől való félelem $(0=$ nincs vagy nem kóros mértékű, ha az összpontszám $<10 ; 1$ = kóros mértékü, ha az összpontszám $\geq 10)$ [23];

- korábbi elesés $(0=$ nem fordult elő; 1 = ha az elmúlt egy évben legalább egy alkalommal előfordult (elesésnek tekintettük azt az eseményt, amelynek során az egyén váratlanul és akaratlanul egy magasabb szintről a talajra vagy egy alacsonyabb felületre került [26, 27]);

- TUG-teszttel mért funkcionális mobilitás $(0=$ életkornak megfelelő; 1 = ha a mozgássor teljesítése 12 másodpercnél több időt vett igénybe) [28];

- gyógyszerszedés ( 0 = ha a következő gyógyszerekból legfeljebb 3 gyógyszert szed rendszeresen: benzodiazepinek, antidepresszánsok, antipszichotikumok, diuretikumok, antiaritmiás szerek, nemszteroid fájdalomcsillapítók; 1 = ha 3 készítménynél többet szed $[29,30]$.

Adataink összehasonlítása során folytonos normális eloszlású adatok esetén kétmintás t-próbát, illetve megfigyelési adatainkra z-tesztet használtunk. Ezután binomiális logisztikus regresszióval ('enter' módszer) elemeztük a függő változó (az eleséstől való félelem), valamint a független változók (az eleséstől való félelemmel feltételezhetően kapcsolatban álló tényezők: életkor, nem, krónikus betegségek száma, funkcionális mobilitás, korábbi elesés, rendszeres gyógyszerszedés) kapcsolatát. Az eleséstől való félelem és a független változók közti kapcsolatot esélyhányados (odds ratio, OR) számításával értékeltük, mely azt mutatja meg, hogy van-e, illetve milyen erős kapcsolat van az adott tényező és az eleséstől való félelem közöttt. Az összefüggés szignifikanciáját a 95\%os konfidenciaintervallum (confidence interval, CI) alapján állapítottuk meg: az eredményt akkor tekintettük szignifikánsnak, ha nem tartalmazta az l-et. A többváltozós modell magyarázó erejét a Nagelkerke-féle $\mathrm{R}^{2}$ megadásával jellemeztük, mely megmutatja, hogy a független változókat tartalmazó modell a függő változó varianciájának hány százalékát magyarázza meg. A statisztikai számításokhoz SPSS (SPSS v18.0) statisztikai 
programot (IBM, Armonk, NY, Amerikai Egyesült Államok), az esélyhányadosok ábrázolására MedCalc programot (MedCalc Software, Ostend, Belgium) használtunk. Szignifikáns eltérésnek a p<0,05 értéket tekintettük.

\section{Eredmények}

Az adatlapot kitöltő 204 személyből 4 személy nem teljesítette a funkcionális mobilitást vizsgáló TUG-tesztet, ezért 200 személy adatait elemeztük, akiknek az átlag-

1. táblázat |A minta jellemzői $(\mathrm{n}=200)$

\begin{tabular}{lc}
\hline & $\begin{array}{l}\text { Átlag }(\mathrm{SD}) \\
\text { vagy } \\
\mathrm{n}(\%)\end{array}$ \\
& $72,4(7,5)$ \\
\hline Életkor (év) & \\
Nem & $182(91)$ \\
Nők & $18(9)$ \\
Férfiak & $127(63,5)$ \\
Egyedül élő & $26,8(4,3)$ \\
BMI (kg/m²) & $54(27)$ \\
Előzó évben elesett & \\
Krónikus betegségek & $128(64)$ \\
Hypertonia & $84(42)$ \\
Osteoporosis & $88(44)$ \\
Az alsó végtagot érintő mozgásszervi betegség & $40(20)$ \\
Cardialis betegség & $32(16)$ \\
Diabetes mellitus & $18(9)$ \\
Respiratorikus betegség & $8(4)$ \\
Az alsó végtagot érintő neurológiai betegség & $61(31)$ \\
Az eleséstől való kóros mértékű félelem &
\end{tabular}

$\mathrm{BMI}=$ testtömegindex

2. táblázat Az eleséstôl nem félő és az eleséstől kóros félelmet mutató csoport összehasonlítása

\begin{tabular}{|c|c|c|c|}
\hline & $\begin{array}{l}\text { Nem fél } \\
\text { az eleséstól } \\
(\mathrm{n}=139)\end{array}$ & $\begin{array}{l}\text { Fél az eleséstől } \\
(\mathrm{n}=61)\end{array}$ & p-érték \\
\hline Életkor (év), átlag \pm szórás & $69,2 \pm 5,8$ & $79,4 \pm 5,9$ & $<0,001$ \\
\hline Férfiak, n (\%) & $9(65)$ & $9(14)$ & 0,061 \\
\hline $\begin{array}{l}\text { Funkcionális mobilitás } \\
\text { (TUG-teszt), átlag } \pm \text { szórás }\end{array}$ & $10,11 \pm 2,2$ & $15,5 \pm 3,3$ & $<0,001$ \\
\hline $\begin{array}{l}\text { A TUG-tesztet a normálérték } \\
\text { (12 mp) felett teljesíti, n (\%) }\end{array}$ & $25(33,8)$ & $49(66,7)$ & $<0,001$ \\
\hline $\begin{array}{l}\text { Háromnál több gyógyszert } \\
\text { szed rendszeresen, n (\%) }\end{array}$ & $39(28)$ & $30(49)$ & 0,004 \\
\hline $\begin{array}{l}\text { Krónikus betegségek száma, } \\
\text { átlag } \pm \text { szórás }\end{array}$ & $1,6 \pm 1,1$ & $2,9 \pm 1,4$ & $<0,001$ \\
\hline Előző évben elesett, n (\%) & $28(20)$ & $26(42)$ & 0,001 \\
\hline
\end{tabular}

TUG = időzített felállási és járási teszt
3. táblázat |A demográfiai, és egészségbeli tényezók, valamint az eleséstól való félelem gyakorisága közötti összefüggés logisztikus regreszsziós elemzésének eredménye

\begin{tabular}{lll}
\hline & $\begin{array}{l}\text { Esélyhányados } \\
\text { és 95\%-os } \\
\text { konfidencia- } \\
\text { intervallum; } \\
\text { nyersértékek }\end{array}$ & $\begin{array}{l}\text { Esélyhányados } \\
\text { és 95\%-os } \\
\text { konfidencia- } \\
\text { intervallum; nemre } \\
\text { adjusztált értékek }\end{array}$ \\
\hline Életkor & $1,27(1,16-1,39)$ & $1,26(1,15-1,38)$ \\
Nem & & $0,41(0,05-3,44)$ \\
Krónikus betegségek száma & $2,37(1,45-3,87)$ & $2,27(1,37-3,77)$ \\
$\begin{array}{l}\text { Határértéknél (12 mp) } \\
\text { rosszabb funkcionális } \\
\text { mobilitás }\end{array}$ & 9,02 & 9,05 \\
$\begin{array}{l}\text { Előzó évben történt elesés } \\
(3,29-24,68)\end{array}$ & $0,76(0,27-2,16)$ & $0,81(0,28-2,36)$ \\
$\begin{array}{l}\text { Háromnál több gyógyszer } \\
\text { szedése }\end{array}$ & $0,46(0,14-1,51)$ & $0,48(0,15-1,61)$ \\
\hline
\end{tabular}

életkora közel 73 év volt: a legfiatalabb 60 éves, míg a legidősebb 93 éves volt. A nók aránya 91\% volt. A minta közel kétharmada egyedül élt. A résztvevők több mint 40\%-a osteoporosisban, illetve az alsó végtagot érintő mozgásszervi betegségben, egyötöde cardialis betegségben szenvedett. Az egyéb jellemzőket, valamint az eleséstől félő, illetve nem félő csoportot az 1. és a 2. táblázat mutatja be. Az eleséstől való félelem összesen 61 személyre (31\%; férfi: $\mathrm{N}=9$; nő: $\mathrm{N}=52$ ) volt jellemző.

Tekintve, hogy a minta 91\%-át nők képezték, a bináris logisztikus regressziós analízist a nemre adjusztálva is elvégeztük. Mivel a nemnek nem volt szignifikáns hatása, a többváltozós modellek nyers és nemre adjusztált regressziós paraméterei között nem volt lényeges eltérés (3. táblázat). Az 1. ábrán az adjusztált többváltozós modell eredményeit mutatjuk be.

Életkor

Krónikus betegségek száma

Határértéknél rosszabb funkcionális mobilitás

Előző évben történő elesés

3-nál több gyógyszer szedése

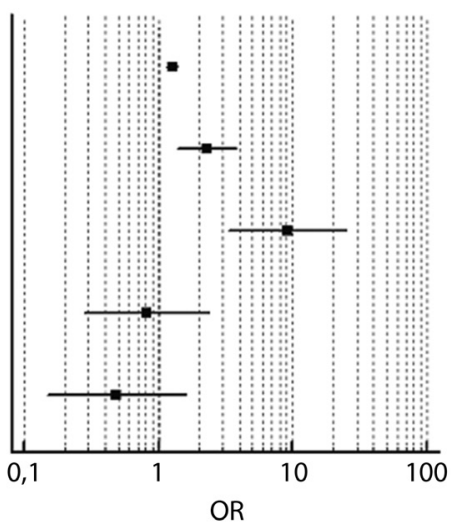

1. ábra

A független változók hatása az eleséstől való félelemre. A logaritmikus skálázású vízszintes tengely az esélyhányados $(\mathrm{OR}$, odds ratio) tengelye. Az l-es értéken áthaladó függóleges vonal a nullhipotézisnek felel meg, amikor is a vizsgált tényező nem függ össze az eleséstól való félelemmel. A függólegestől balra eső pontok protektív hatást, míg a jobb oldali pontok veszélyeztető hatást jeleznek. Ha a pontokhoz tartozó vízszintes sáv, a konfidenciaintervallum sávja átlóg a függóleges vonalon, a tényezőnek nincs szignifikáns hatása 
Az eredmények szerint az életkor és az eleséstől való kóros mértékű félelem között szignifikáns kapcsolat áll fent: egyévnyi öregedéssel közel 30\%-kal emelkedik annak valószínűsége, hogy az idős ember a mindennapi tevékenységei során kóros mértékben fél az eleséstól. Ugyancsak szignifikáns kapcsolat igazolódott az idős életszakaszt jellemző krónikus betegségek száma és az eleséstől való félelem között: minden további betegség több mint a kétszeresére emeli az eleséstől való kóros mértékű félelem valószínűségét. A funkcionális mobilitás és az eleséstől való félelem között is szignifikáns kapcsolat igazolódott: ha az idős ember a populációra jellemző határértéknél, azaz 12 mp-nél hosszabb idő alatt teljesíti a tesztet, akkor több mint kilencszer nagyobb az eleséstől való félelem kialakulásának valószínúsége. A megelőző egy éven belüli elesés hatása, valamint az, hogy az idős személy a vizsgált hatóanyag-tartalmú gyógyszerkészítmények közül háromnál többet szed, nem bizonyult szignifikánsnak.

A szignifikáns kapcsolatot mutató tényezőkből álló, nemre adjusztált modellünk a függő változó varianciájának közel 70\%-át magyarázza (Nagelkerke-féle $\mathrm{R}^{2}=$ $0,695)$.

\section{Megbeszélés}

Kutatásunkban azt vizsgáltuk meg, hogy magyar, otthon élő idősek körében milyen összefüggés mutatkozik a demográfiai (életkor, nem), valamint az egészségbeli (az idős életszakaszra jellemző krónikus betegségek, funkcionális stabilitás, a megelőző egy éven belüli elesés, gyógyszerszedés) tényezők és az eleséstől való félelem között. Eredményeink alapján felvetődött az életkor, a krónikus betegségek és a rossz funkcionális mobilitás veszélyeztető hatása, míg a nemmel, a korábbi eleséssel és a gyógyszerszedéssel való kapcsolat nem igazolódott.

A szakirodalmi adatok alapján az eleséstől való félelem az idősek jelentős hányadát érinti. Otthon élő, önálló életvitelt folytató idősek körében Murphy és Williams (72 évnél idősebb mintán) 24\%-ra, Arfken (66 év feletti mintán) 29\%-ra, Vellas (60 évnél idősebb mintán) 32\%-ra becsüli a gyakoriságát. Egy 70 év felettiek körében, nagy elemszámú mintán végzett felmérésben Zijlstra 54,3\%os prevalenciát mutatott ki [7-10]. Mi a mintánkban 31\%-os gyakoriságot találtunk.

Számos kutatás vizsgálta azt is, hogy az idősek eleséstől való félelme összefügg-e demográfiai (életkor, nem) és egészséggel összefüggő (társbetegségek, fizikális funkcionális képességek, elesés) tényezőkkel.

\section{Összefüggés az életkorral és a nemmel}

A kutatások szerint az eleséstől való félelem összefügg az életkorral és a nemmel, bár az eredmények nem konzisztensek. Az eredmények egy része arra mutat rá, hogy a jelenség a nők között gyakoribb, és az életkor előrehaladásával a gyakorisága emelkedik. Arfken eredményei sze- rint a 66-70 év közötti nők 21\%-a, a férfiak 14\%-a fél az eleséstől, míg 81 év felett ezek az arányok 45\%-ra, illetve 21\%-ra emelkednek [8]. Zijlstra arról számol be, hogy 80 év felett közel $80 \%$-kal nő az eleséstől való félelem kialakulásának kockázata (OR: 1,79, 95\% CI: 1,49-2,16) [10]. Kempen szerint is gyakoribb a nők körében (OR: 2,28, 95\% CI: 1,41-3,69) az eleséstől való félelem [14].

Ezekkel szemben két másik kutatás nem talált összefüggést az életkor és az eleséstől való félelem között [5, 15]. Továbbá Howland nem talált szignifikáns különbséget a két nem közötti gyakoriságban sem [5].

\section{Összefüggés a társbetegségekkel}

Bizonyos neurológiai kórképekben (stroke, Parkinsonkór), hypertoniában, arthrosisban, osteoporosisban szenvedők gyakrabban számolnak be eleséstől való félelemről $[4,17,20]$. Fletcher keresztmetszeti kutatásában azt vizsgálta, hogy az időskort jellemző társbetegségek milyen mértékben járulnak hozzá ahhoz, hogy az idős egyének napi tevékenységeit is korlátozzák. Kimutatta, hogy a szívbetegség 36\%-kal (OR: 1,36, 95\% CI: 1,041,49), az arthrosis 45\%-kal (OR: 1,45, 95\% CI: 1,171,80 ), az osteoporosis 55\%-kal (OR: $1,55,95 \% \mathrm{CI}$ : 1,13-2,12), a zöld vagy szürke hályog 30\%-kal (OR: 1,30, 95\% CI: 1,01-1,67) növelte annak valószínüségét, hogy az idős személy az eleséstől tartva visszafogja azokat a fizikai aktivitásait, amelyeket egyébként el tudna végezni [20]. A gyógyszerszedés ugyancsak szignifikáns összefüggést mutat az eleséstől való félelemmel. Friedman kimutatta, hogy azok körében, akik rendszeresen négynél több gyógyszert szednek, 68\%-kal valószínúbb (OR: 1,68, 95\% CI: 1,34-2,12), hogy indokolatlanul félnek az eleséstől [17].

\section{Összefüggés a fizikai funkcionális állapottal}

A kutatások többsége kimutatta az eleséstől való félelem szignifikáns kapcsolatát a bizonytalanabb egyensúllyal és a rosszabb járásképességgel.

Az eleséstől tartó idősek alsó végtagi izomzata szignifikánsan gyengébb volt, és a járástesztekben is rosszabb eredményt mutattak [18]. Arfken vizsgálatában az eleséstől félő idősek 91\%-a a funkciózavarok (járászavar, lépcsőn járási képtelenség segítség nélkül, látászavar, rossznak ítélt egészségi állapot, járási segédeszköz használata) közül legalább eggyel rendelkezett. Ezzel szemben az eleséstől nem félőknek csak az 59\%-a szenvedett az előzőek valamelyikében [8]. Ezt erősíti meg Vellas kutatása is, melyben az eleséstől félő idősek között szignifikánsan gyakrabban volt tapasztalható járászavar (31,9\%) vagy egyensúlyzavar $(31 \%)$, szemben az eleséstől nem félőkkel (7,4\% és 12,8\%) [9]. Kressig prospektív vizsgálatában azok körében, akiknek a járássebessége 0,9 $\mathrm{m} / \mathrm{s}$-nál kisebb volt, háromszor nagyobb volt az eleséstől való félelem kialakulásának valószínúsége (OR: 3,1, 95\% CI: 1,9-5,1) [15]. Brouwer eredményei szerint az 
eleséstől tartó idősek járássebessége 12\%-kal volt kisebb, továbbá az alsó végtag izomzatának ereje is szignifikánsan gyengébb volt, és a székről is nehezebben tudtak felállni [19]. Lach 2 éves utánkövetéses vizsgálatában viszont nem igazolódott az, hogy nagyobb az eleséstől való félelem kialakulásának kockázata azoknál, akik a lépcsőn járásban segítségre szorulnak (OR: 1,03, 95\% CI: 0,51-2,05), járási segédeszközt használnak (OR: 0,11, 95\% CI: 0,14-1,56), vagy akiknek az egyensúlya roszszabb (OR: 1,06, 95\% CI: 0,79-1,43) [16].

\section{Összefüggés az eleséssel}

A vizsgálatok az elesés és az eleséstől való félelem között kölcsönös összefüggést mutatnak. Arfken 12 hónapos követéses vizsgálatában kimutatta, hogy az eleséstől félő személyek 9\%-a korábban töréssel járó elesést szenvedett, míg a nem félők között ez az arány csak $0,5 \%$ volt [8]. Kempen arról számolt be, hogy a megelőző 6 hónapon belüli elesés közel 50\%-kal emelte az eleséstől való félelem kockázatát (OR: 1,49, 95\% CI: 1,01-2,20) [14]. Zijlstra szerint azon időseknél, akik a megkérdezést megelőző egy éven belül elestek, majdnem a hatszorosa volt annak valószínüsége, hogy kialakul az újabb eleséstől való félelem (OR: 5,72, 95\% CI: 4,49-7,43) [10]. Ezt erősíti meg Lach is, aki 2 éves követéses vizsgálatában azt mutatta ki, hogy kettőnél több elesés majdnem a négyszeresére növeli annak valószínúségét, hogy az idős ember félni fog egy újabb eleséstől (OR: 3,90, 95\% CI: $1,14-13,37)$ [16].

Fordított kapcsolat is fennáll az elesés és az eleséstől való félelem között: azon időseknél, akik félnek az eleséstől, valóban nagyobb az elesés kockázata. Cumming 12 hónapos követéses vizsgálatában az elesés kockázata kétszer nagyobb volt az eleséstől félők, mint a nem félők esetében (RR: 2,09, 95\% CI: 1,31-3,33) [4]. Az elesés és az eleséstől való félelem időbeli kapcsolatát Friedman vizsgálta egy 2212 fős mintán végzett prospektív kutatásban: 20 hónapos követési időszak elején és végén mérte fel az elesések és az eleséstől való félelemről beszámoló idősek számát [17]. Kimutatta, hogy akik a vizsgálat elején elesési anamnézissel rendelkeztek, 20 hónappal később 75\%-kal nagyobb arányban számoltak be arról, hogy félnek az eleséstól (OR: 1,75, 95\% CI: 1,30-2,36). Fordítva is igaz a kapcsolat: akiknél eleséstől való félelmet tapasztaltak, 79\%-kal gyakrabban estek el a követési időszak végére (OR: 1,79, 95\% CI: 1,33-2,42).

Akár az elesés, akár az eleséstől való félelem tapasztalható az idős embernél, fennáll a kockázata annak, hogy elkezdődik egy funkcionális hanyatláshoz vezető kaszkádszerü folyamat.

Kutatásunk hiányosságának tekinthető a szelektív mintaválasztás: a 60 évesnél idősebb, (még ha segédeszközzel is, de) mozgásképes, bizonyos fokú társasági életet élő személyek kerültek beválogatásra, ami az eredmé- nyeink általánosíthatóságát elsősorban erre a populációra korlátozza.

Kutatásunk azoknak a kutatásoknak az eredményeit erősíti, melyek szerint az életkor emelkedése, az idős életszakaszt jellemző krónikus betegségek száma és a hanyatló funkcionális mobilitás áll kapcsolatban az eleséstől való félelemmel. Ezért a magas életkorú, több krónikus betegségben szenvedő, hanyatló funkcionális mobilitású idősek körében szükséges a könnyen kitölthető rövid FES-I kérdőívvel kiemelni azokat az időseket, akik körében részletes kikérdezéssel, fizikális vizsgálatokkal és az otthoni környezet veszélyforrásainak szisztematikus feltárásával tudjuk az elesés rizikótényezőit azonosítani [31-33]. Az idős embert ezt követően vonhatjuk be olyan többtényezős programba, melyben a krónikus betegségeket kezelő orvos munkáját a gyógytornász megfelelő mozgásprogrammal, a pszichológus vagy pszichiáter kognitív viselkedésterápiával tudja kiegészíteni [34, 35].

\section{Következtetés}

Az eleséstől való félelem akkor tekinthető kórosnak, ha az idős emberek a félelem miatt elkerülnek olyan tevékenységeket, amelyeket egyébként el tudnának végezni. Emiatt fizikai állapotuk hanyatlik: izomzatuk gyengül, egyensúly-szabályozásuk romlik, végül az idős emberek elvesztik önellátó képességüket, és intézeti ellátásra szorulnak. Ennek elkerüléséért nagyon fontos, hogy időben felismerjük és megfelelő prevenciós programba vonjuk azokat az időseket, akik mindennapi tevékenységeik során indokolatlanul félnek az eleséstől. Az egyszerűen és gyorsan kitölthető, magyar nyelven is validált, rövid FES-I kérdőívvel elsősorban a magasabb életkorú, több krónikus betegségben szenvedő időseket érdemes szûrni, hogy azonosítsuk azokat, akik további részletes kivizsgálásra, majd ennek eredménye alapján célzott beavatkozásra szorulnak.

Anyagi támogatás: A közlemény megírása, illetve a kapcsolódó kutatómunka anyagi támogatásban nem részesült.

Szerzői munkamegosztás: K. É.: A kézirat elkészítése, a hipotézisek kidolgozása, a vizsgálat megtervezése, statisztikai elemzés. E. R. L., P. A. N., R. F.: A vizsgálat megtervezése, lefolytatása. S. A.: A vizsgálat megtervezése, statisztikai elemzés, a kézirat elkészítése. A szerzők a cikk végleges változatát elolvasták és jóváhagyták.

Érdekeltségek: A szerzőknek nincsenek érdekeltségeik.

\section{Köszönetnyilvánítás}

A szerzők köszönetüket fejezik ki Dr. Deutsch Tibor főiskolai tanárnak a statisztikai számításokban nyújtott segítségéért. 


\section{Irodalom}

[1] United Nations, Population Division of the Department of Economic and Social Affairs of the United Nations Secretariat. World Population Prospects: The 2008 Revision. New York, NY, 2008. Available from: http://esa.un.org/unpp [accessed: July 20, 2017].

[2] Bhala RP, O'Donnell J, Thoppil E. Ptophobia. Phobic fear of falling and its clinical management. Phys Ther. 1982; 62: 187190.

[3] Murphy J, Isaacs B. The post-fall syndrome. A study of 36 elderly patients. Gerontology 1982; 28: 265-270.

[4] Cumming RG, Salkeld G, Thomas M, et al. Prospective study of the impact of fear of falling on activities of daily living, SF-36 scores, and nursing home admission. J Gerontol A Biol Sci Med Sci. 2000; 55: M299-M305.

[5] Howland J, Peterson EW, Levin WC, et al. Fear of falling among the community-dwelling elderly. J Aging Health 1993; 5: 229243.

[6] Legters K. Fear of falling. Phys Ther. 2002; 82: 264-272.

[7] Murphy SL, Williams CS, Gill TM. Characteristics associated with fear of falling and activity restriction in community-living older persons. J Am Geriatr Soc. 2002; 50: 516-520.

[8] Arfken CL, Lach HW, Birge SJ, et al. The prevalence and correlates of fear of falling in elderly persons living in the community. Am J Public Health 1994; 84: 565-570.

[9] Vellas BJ, Wayne SJ, Romero LJ, et al. Fear of falling and restriction of mobility in elderly fallers. Age Ageing 1997; 26: 189193.

[10] Zijlstra GA, van Haastregt JC, van Eijk JT, et al. Prevalence and correlates of fear of falling, and associated avoidance of activity in the general population of community-living older people. Age Ageing 2007; 36: 304-309.

[11] Tinetti ME, Powell L. Fear of falling and low self-efficacy: a case of dependence in elderly persons. J Gerontol. 1993; 48: 35-38.

[12] Jørstad EC, Hauer K, Becker C, et al., on behalf of the ProFaNE Group. Measuring the psychological outcomes of falling: a systematic review. J Am Geriatr Soc. 2005; 3: 501-510.

[13] Kendrick D, Kumar A, Carpenter H, et al. Exercise for reducing fear of falling in older people living in the community. Cochrane Database Syst Rev. 2014; 11: CD009848.

[14] Kempen GI, van Haastregt JC, McKee KJ. Socio-demographic, health-related and psychosocial correlates of fear of falling and avoidance of activity in community-living older persons who avoid activity due to fear of falling. BMC Public Health 2009; 9: 170.

[15] Kressig RW, Wolf SL, Sattin RW, et al. Associations of demographic, functional, and behavioral characteristics with activityrelated fear of falling among older adults transitioning to frailty. J Am Geriatr Soc. 2001; 49: 1456-1462.

[16] Lach HW. Incidence and risk factors for developing fear of falling in older adults. Public Health Nurs. 2005; 22: 45-52.

[17] Friedman SM, Munoz B, West SK, et al. Falls and fear of falling: which comes first? A longitudinal prediction model suggests strategies for primary and secondary prevention. J Am Geriatr Soc. 2002; 50: 1329-1335.

[18] Gillespie SM, Friedman SM. Fear of falling in new long-term care enrollees. J Am Med Dir Assoc. 2007; 8: 307-313.

[19] Brouwer B, Musselman K, Culham E. Physical function and health status among seniors with and without a fear of falling. Gerontology 2004; 50: 135-141
[20] Fletcher PC, Hirdes JP. Restriction in activity associated with fear of falling among community-based seniors using home care services. Age Ageing 2004; 33: 273-279.

[21] Kovács É, Rozs F, Petridisz A, et al. Cross-cultural validation of the Falls Efficacy Scale - International to assess concerns about falls among Hungarian community-living older people. Disabil Rehabil. 2018; 40: 3070-3075.

[22] FES-I Falls Efficacy Scale - International. Available from: https://blogs.manchester.ac.uk/fes-i/wp-content/uploads/ sites/11/2018/03/Short_FES-I_Hungarian.pdf [accessed: July 20, 2018]. [Hungarian]

[23] Delbaere K, Close JC, Mikolaizak AS, et al. The Falls Efficacy Scale International (FES-I). A comprehensive longitudinal validation study. Age Ageing 2010; 39: 210-216.

[24] Podsiadlo D, Richardson S. The timed "Up \& Go": a test of basic functional mobility for frail elderly persons. J Am Geriatr Soc. 1991; 39: 141-148.

[25] VanSwearingen JM, Brach JS. Making geriatric assessment work: selecting useful measures. Phys Ther. 2001; 81: 1233-1252.

[26] Nevitt MC, Cummings SR, Kidd S, et al. Risk factors for recurrent nonsyncopal falls. A prospective study. JAMA 1989; 261: 2663-2668.

[27] Lamb SE, Jørstad-Stein EC, Hauer K, et al. Development of a common outcome data set for fall injury prevention trials: the Prevention of Falls Network Europe consensus. J Am Geriatr Soc. $2005 ; 53$ : 1618-1622.

[28] Bischoff HA, Stähelin HB, Monsch AU, et al. Identifying a cutoff point for normal mobility: a comparison of the timed "up and go" test in community-dwelling and institutionalised elderly women. Age Ageing 2003; 32: 315-320.

[29] Rubenstein LZ. Falls in older people: epidemiology, risk factors and strategies for prevention. Age Ageing 2006; 35(Suppl 2) ii37-ii4l.

[30] Rubenstein LZ, Josephson KR. Falls and their prevention in elderly people: what does the evidence show? Med Clin North Am. 2006; 90: 807-824.

[31] Székács B, Martony Zs. Falls in the elderly [Elesés idős korban.] Idősgyógyászat 2018; 2: 14-19. [Hungarian]

[32] Centers for Disease Control and Prevention. Algorithm for fall risk assessment and intervention. Atlanta, GA. Available from http://www.cdc.gov/homeandrecreationalsafety/pdf/steadi/ algorithm_fall_risk_assessment.pdf [accessed: July 20, 2017].

[33] Panel on Prevention of Falls in Older Persons, American Geriatrics Society and British Geriatrics Society. Summary of the Updated American Geriatrics Society/British Geriatrics Society clinical practice guideline for prevention of falls in older persons. J Am Geriatr Soc. 2011; 59: 148-157.

[34] Zijlstra GA, van Haastregt JC, van Rossum E, et al. Interventions to reduce fear of falling in community-living older people: a systematic review. J Am Geriatr Soc. 2007; 55: 603-615.

[35] Dorresteijn TA, Zijlstra GA, Ambergen AW, et al. Effectiveness of a home-based cognitive behavioral program to manage concerns about falls in community-dwelling, frail older people: results of a randomized controlled trial. BMC Geriatr. 2016; 16: 2.

(Kovács Éva dr., Budapest, Vas u. 17., 1088 e-mail: kovacse@se-etk.hu)

A cikk a Creative Commons Attribution 4.0 International License (https://creativecommons.org/licenses/by/4.0/) feltételei szerint publikált Open Access közlemény, melynek szellemében a cikk bármilyen médiumban szabadon felhasználható, megosztható és újraközölhetö, feltéve, hogy az eredeti szerző és a közlés helye, illetve a CC License linkje és az esetlegesen végrehajtott módositások feltüntetésre kerülnek. (SID_1) 